\title{
The Nature of Sorghum Halepense (L.) Pers. Spatial Distribution Patterns in Tomato Cropping Fields
}

\author{
Dionisio Andújar • Victor Rueda-Ayala • \\ Markus Jackenkroll • José Dorado • Roland Gerhards • \\ César Fernández-Quintanilla
}

Received: 10 June 2013 / Accepted: 26 June 2013 / Published online: 1 August 2013

(C) Springer-Verlag Berlin Heidelberg 2013

\begin{abstract}
Spatial distribution of Sorghum halepense (L.) Pers. populations was assessed in tomato cropping fields in a total of 11 commercial fields (93 ha). Weed infestation was visually assessed from the cabin of a tractor after harvesting, using a three category ranking, 'high', 'low', and 'no presence', through infestation maps. Crop management factors as well as intrinsic parameters of patches were collected and calculated. The proportion of the field infested with low and high $S$. halepense densities, patch anisotropy, the effect of field borders and field topography were studied. On average, 5 and $3 \%$ of the surveyed area was infested with high and low densities, respectively. The majority of patches were of small size and most of the infested area was concentrated in a few large patches with irregular shape. Small patches, those with less than $50 \mathrm{~m}^{2}$, represented $70 \%$ of the total number of detected patches. However, they only accounted for the $3 \%$ of infested area. Tillage operations showed a great influence on patch shape, producing patches twice longer in the direction of tillage than perpendicular to tillage. This result revealed the influence of human operations in S. halepense spreading. The effect of edges also had a great influence in patch expansion. Patches in contact with a field border were almost five times longer than their width in the direction of tillage. Also, the effect of borders stimulated the infestation. Areas closer to the borders had a higher risk of $S$. halepense infestation than zones in the center of the fields. In addition, patches tended to increase complexity the big-
\end{abstract}

V. Rueda-Ayala $(\bowtie) \cdot$ D. Andújar $\cdot$ M. Jackenkroll $\cdot$ R. Gerhards Department of Weed Science (360b), University of Hohenheim, Otto-Sander-Str. 5b, 70599 Stuttgart, Germany e-mail: victor.Rueda.Ayala@uni-hohenheim.de

J. Dorado · C. Fernández-Quintanilla

Institute of Agricultural Sciences, CSIC, 28006 Madrid, Spain ger they became, with a progressive shrinkage in the ratio area/perimeter ${ }^{2}$. The influence of location within the field revealed that higher levels of infestation were found on the lowest and closest areas to riverbeds, in areas with flooding risk. Characterizing the location of $S$. halepense patches after harvesting offers a precise and cheap method for the construction of weed maps, which can be used for sitespecific treatments and description of weed spatial biology.

Keywords Patch spraying - Weed population dynamics · Mapping

\section{Die Beschaffenheit von Sorghum halepense (L.) Pers.- Verteilungsmustern im Tomatenanbau}

Zusammenfassung Die räumliche Verteilung von Sorghum halepense (L.) Pers.-Gesellschaften wurde in elf, zum kommerziellen Tomatenanbau genutzten Feldern (93 ha) untersucht. Der Unkrautbefall wurde nach der Ernte visuell von der Traktorkabine beurteilt und in drei Kategorien, „hoch“, „,niedrig“, „kein Vorkommen“, für Befallskarten eingestuft. Sowohl die Faktoren der Feldbewirtschaftung, als auch die Eigenparameter von Unkrautnestern wurden gesammelt und berechnet. Das Verhältnis von Feldern mit einer geringen und hohen Befallsdichte von S. halepense, die Anisotropie der Nester, der Einfluss von Feldgrenzen und die Feld-Topographie wurden untersucht. Im Durchschnitt waren 5 und $3 \%$ der beobachteten Flächen stark bzw. leicht befallen. Hauptsächlich traten kleine Nester auf und befallene Gebiete bestanden aus wenigen großen Nestern mit unregelmäßigen Umrissen. Kleine Nester mit weniger als $50 \mathrm{~m}^{2}$, repräsentieren $70 \%$ der insgesamt beobachteten Nester. Jedoch beanspruchen sie nur 3\% der befallenen Flächen. Bodenbearbeitung mittels Pflug zeigt 
einen großen Einfluss auf die Nestform: Unkrautnester sind in Bearbeitungsrichtung doppelt so lang wie orthogonal zu dieser. Das Ergebnis zeigt den Einfluss der Bearbeitung auf die Ausbreitung von S. halepense. Auch Ränder haben einen großen Einfluss auf die Nestausbreitung. Nester am Rand eines Feldes waren in Pflugrichtung nahezu fünfmal so lang, wie breit in Pflugrichtung. Darüber hinaus lässt sich ein grundsätzlich verstärkender Effekt der Feldgrenzen auf den Befall nachweisen. Grenznahe Gebiete haben ein erhöhtes Risiko durch S. halepense befallen zu werden, als Regionen im Inneren eines Feldes. Zudem tendieren Nester zu erhöhter Komplexität je größer sie werden. Das Verhältnis Fläche/Umfangareal ${ }^{2}$ schrumpft progressiv. Der Einfluss von Positionen innerhalb des Feldes zeigt deutlich, dass höhere Befallsstufen bei den niedrigsten und nächsten Flächen zu Flussbetten, also Hochwasserrisikogebieten, gefunden wurden. Die Charakterisierung von Gebieten mit $S$. halepense Nestern nach der Ernte stellt eine genaue und günstige Methode zur Erstellung von Unkrautkarten dar, die zur ortsbezogenen Behandlung und räumlichen Beschreibung der Unkrautbiologie genutzt werden.

Schlüsselwörter Teilschlagspezifische Unkrautkontrolle · Unkrautpopulationsdynamik · Unkrautkartierung

\section{Introduction}

Mostly, weed populations have a patchy distribution within the arable fields (Cardina et al. 1995; Johnson et al. 1996). The use of this information and the understanding of weed behaviour could improve the management of these populations. The number of factors affecting the patch distribution is difficult to fix. However, weed population dynamic tries to describe the influence of various attributes and their interactions with the patchiness generation. The first step to analyse these processes is to define a patch. A weed patch could be described as an area in which individuals are aggregated into a discrete subdivided population, with its edges defined as a measure of the population, such as density, different from that found within the delimited area (Dieleman and Mortensen 1999). These patches are spatially heterogeneous in the fields, thus a major issue to study them is patch detection.

In general, patch stability is higher in perennial species than in annuals due to their vegetative reproduction. Annual weeds are less persistent spatially and have a higher capacity of colonization of weed-free areas. Spatial aggregation of perennial plants gives an opportunity to study the evolution of patches throughout the years; it also allows easy localization of a patch from year to year. This effect is common in most of perennial species such as Apocynum cannabinum $\mathrm{L}$. (Webster et al. 2000), Cirsium arvense (L.) Scop. (Donald
1994), and Sorghum halepense (L.) Pers. (Andújar et al. 2012). The latter, S. halepense, is the target in this study, and it is extremely competitive with most row crops. Spanish conditions with warm temperatures and high humidity under irrigation systems are optimal for its development. $S$. halepense is a problematic weed that causes serious yield and economic losses and it is considered one of the most troublesome weeds in the world (Holm 1969). It has patchy distribution and it is usually controlled with expensive postemergence herbicides. These characteristic make it an ideal target of site-specific weed management, allowing a substantial reduction in herbicide use by patch spraying (Brain and Cousens 1990). Characterizing its behaviour and understanding the spatial patterns is important for improving the effectiveness of management strategies. For instance, aggregated pattern is one of the best characteristics that allows specific spraying of herbicides only to the infested zones. This reduces considerably the amount of applied herbicides, with the associated benefits of economic savings and reduction of environmental impact.

The economic benefits of herbicide reduction and the environmental impact of site-specific spraying were evaluated during four years in maize fields infested with S. halepense by Andújar et al. (2012). It was found that the most economic strategy was to spray herbicide sitespecifically, resulting in herbicide reductions higher than $50 \%$ compared to a traditional management. However, the benefits of SSWM are highly dependent of patch characteristics and intrinsic factors of the crop. Thus, SSWM is conditioned by the crop value, the proportion of the field infested by weeds, the shape and number of patches and the technologies for sampling and spraying (Barroso et al. 2004; Ruiz et al. 2006). These parameters are necessary to determine a correct management. High value crops with a small proportion of the field infested by weeds are the ideal target for patch spraying, because they justify the associated cost of detection and site-specific spraying. In addition, large and regular patches reduce the economic effort by the farmers, since patches become easier to detect and spray.

Adoption of SSWM is not only depending on the economic benefits and the environmental consciousness of the farmers. Some Directives of the European Union lead to a reduction of the used inputs for pest control (European Council 2009), which indirectly promotes the adoption of precision agriculture technologies, such as patch spraying. This effect has been shown in some studies. Ruiz et al. (2006) found that patch spraying could reduce the amount of applied herbicides against wild oats in cereal crops. Gerhards and Christensen (2003) obtained high herbicides savings using SSWM technologies in various crops. Similarly, Andújar et al. (2011) working with $S$. halepense concluded that patches were mostly located in some predictable parts of the field, and site-specific treatments of these areas could 
reduce herbicide inputs. Thus, the understanding of weed spatial biology is needed. In addition, this information is more valuable in high economic crops, such as tomato. Tomato is highly susceptible to yield losses by weeds and weed control supposes the highest investment by the farmers. The aims of this study were (I) to show the spatial pattern of S. halepense in tomato crops, and (II) to describe the effect of some environmental variables in the presence of this weed.

\section{Materials and Methods}

Field data collection was carried out during 2009 in eleven tomato fields (93 ha in total) after harvesting (SeptemberOctober) from the cabin of a tractor. The evaluated fields were located in Extremadura $\left(39^{\circ} 1^{\prime} \mathrm{N}, 6^{\circ} 3^{\prime} \mathrm{E}\right.$, South-west Spain). This region is characterized by hight temperatures and low precipitations from spring to autumn. However, irrigation practices created a high humidity atmosphere in tomato cropping fields, which favored the growth of $S$. halepense. Soils were generally sandy with low organic content. The major crops were tomato and maize. Rotation between these two crops was the common strategy. Fields received various treatments with postemergence herbicides (rimsulfuron or nicosulfuron) before harvesting. Cynodon dactylon was present in every evaluated field, being the most significant weed in this area. However, S. halepense produced a high impact in the rotation, due to competition with maize. In addition, this weed produces problems during tomato harvesting owing to its high biomass production that blocks the swather of the harvesters. The control of this weed is a major issue in this region that produces over $80 \%$ of the total Spanish production, with more than 17,000 ha of tomato for industry (MAPA 2013).

Patch distribution maps of $S$. halepense were created, based on visual assessments from a tractor three weeks after harvesting, following the procedure described by Andújar et al. (2012). This period after harvest was enough for $S$. halepense to regrow and become visible again. Three infestation levels were used for sampling: " 0 " as used for non-infested areas, " 1 " was equivalent to low density areas (0-7 plants $\left.\mathrm{m}^{-2}\right)$, and "2" was used for those places with a high density of $S$. halepense ( $>7$ plants $\mathrm{m}^{-2}$ ). The construction of the original files was rather simple, thanks to the easy identification of $S$. halepense plants after harvesting. They were clearly visible among crop residues which were completely dry, while the emerging weed plants were erect and green. Due to the high stability of this weed from year to year (Andújar et al. 2012), this methodology for weed mapping is an easy and cheap tool for the management of this weed in the subsequent year. Given the high competitiveness of this weed, the presence of only one plant was marked as infested zone. Since the tractor was driven with a constant speed of $8 \mathrm{~km} \mathrm{~h}^{-1}$, the distance between points in the same row was $2 \mathrm{~m}$ approximately. The distance between transects was $4.5 \mathrm{~m}$, equivalent to three row crops. Data were collected using a DGPS (Hemisphere Crescent R130, Hemisphere GPS, Calgary, AB, Canada) with Omnistar correction and a Tablet PC (Itronix Duo-Touch ${ }^{\mathrm{TM}}$ Tablet PC, General Dynamics, Sawgrass Corporate Parkway, FL, USA) which allowed to integrate the geo-referenced positions with the density levels of $S$. halepense. The collection software created a data base with the DGPS coordinates and the associated value of $S$. halepense level selected by an operator in the tractor.

\section{Data Processing}

A data file for each evaluated field was treated individually by a cleaning process that eliminated the points with no differential correction. The data set was converted to plane coordinates with an x-y projection to facilitate the data management with a representation in meters. Coincident points with the same coordinates were automatically removed conserving the point with the highest value in case of disagreement. Consecutive points with a distance lower than $0.5 \mathrm{~m}$ into the same row were removed to avoid an uneven distribution. These repetitions occurred due to changes in the speed or places were the tractor coped with obstacles or corners and field edges. Thus, a valid point represented an area of $9 \mathrm{~m}^{2}(2 \mathrm{~m}$ between points into the same row and $4.5 \mathrm{~m}$ between parallel rows).

The next step, was the construction of polygon maps to extract information for the analysis. The management of the spatial data was carried out using ArcGIS ${ }^{\circledR} ; 9.3$ (ESRI, Redlands, California, USA). A inverse distance interpolation methodology was used for this purpose. A $0.5 \times 0.5 \mathrm{~m}$ grid map was created for every field. Cells with a value higher than 0.5 were considered as infested. After the interpolation process, polygons were created by merging adjacent cells with a common value of $S$. halepense presence. Polygons with an area smaller than $5 \mathrm{~m}^{2}$ were counted but not consider into the analysis as patches (Andújar et al. 2011). For every polygon with an area higher than $5 \mathrm{~m}^{2}$, the following attributes were calculated: area, perimeter, and its maximum length parallel and perpendicular to the tillage direction. This allowed identification of the percentage of field infested by $S$. halepense, and the frequency of patch distribution. The ratio area/perimeter ${ }^{2}\left(\mathrm{a} / \mathrm{p}^{2}\right)$ was used to describe the patch shape complexity (Ruiz et al. 2006), with high values corresponding to more regular patches. Patch growing was described by the anisotropy, by dividing the maximum length in the tillage direction by the maximum length perpendicular to tillage. This index showed the influence of agricultural practices on patch spreading. In addi- 
tion, directed variograms of the data were plotted in gslib (Stanford University) to confirm the anisotropic effect.

\section{Autocorrelation Analysis}

The spatial information about weed appearance was tested for clusters by counting joints (Plant 2012). Therefore, the point data were transferred into Thiessen polygons representing the neighborhood of the samples. This was done by the voronoi-tool in Quantum GIS 1.8.0 (QGIS Development Team). Joints were counted with the software package $\mathrm{R}$ (R Foundation for Statistical Computing) using the package spdep (Bivand et al. 2013). Input information were the neighborhoods and the data sets of S. halepense infestation, reduced to the distinction of weed and non-weed samples. Join count test was calculated as the sum of features sharing one boarder and have the same attribute of interest. Compared with the expected number on a field with randomly defined weed-positive or weed-negative areas, it indicated a clustered appearance of $S$. halepense.

\section{Results and Discussion}

From the total surveyed fields using visual estimation and map processing for $S$. halepense, the percentage of infested area ranged from 3 to $40 \%$. On average, less than $5 \%$ of the total area was infested by low density infestations equivalent to less than 7 plants $\mathrm{m}^{-2}$. The case of high density infestations was rather diffuse, with $3 \%$ of the area infested with patches of more than 7 plants $\mathrm{m}^{-2}$. Field size had no influence in the infestation levels. A total of 192 patches were located into the evaluated fields, ranging from $5 \mathrm{~m}^{2}$ (isolated plants) to more than $1000 \mathrm{~m}^{2}$. The majority of patches were of small size with more than $70 \%$ of the total number of patches being included into the category of less than $50 \mathrm{~m}^{2}$. However, this represented only $3 \%$ of the total infested area. On the contrary, large patches, which only accounted for $3 \%$ of the number of patches represented $80 \%$ of the total infested area (Table 1). Similarly, Andújar et al. (2011) showed that $S$. halepense tended to concentrate its infesta-

Table 1 Patch size classes. Number of patches $(n)$ and infested area on each size class, in absolute counts and percentages

\begin{tabular}{lcrlc}
\hline Size class & $\begin{array}{l}\text { Patches } \\
\mathrm{n}^{\circ}\end{array}$ & \multicolumn{1}{l}{$\begin{array}{l}\text { Area } \\
\mathrm{m}^{2}\end{array}$} & $\begin{array}{l}n \\
\text { Percentage }\end{array}$ & $\begin{array}{l}\text { Area } \\
\text { Percentage }\end{array}$ \\
\hline Isolate plant & 80 & 388.50 & 41.67 & 0.66 \\
$<50 \mathrm{~m}^{2}$ & 59 & $1,360.69$ & 30.73 & 2.30 \\
$50-250 \mathrm{~m}^{2}$ & 32 & $3,575.21$ & 16.67 & 6.04 \\
$250-1,000 \mathrm{~m}^{2}$ & 15 & $6,437.85$ & 7.81 & 10.87 \\
$>1,000 \mathrm{~m}^{2}$ & 6 & $47,447.32$ & 3.13 & 80.13 \\
Total & 192 & $59,209.57$ & 100 & 100 \\
\hline
\end{tabular}

tion in large patches in maize fields. The study conducted in 38 fields showed that $1 \%$ of the patches covered more than $70 \%$ of the infested surface. In the case of tomato field the level of infestation was lower, and this effect could be due to the intensive use of herbicides against this weed. In maize production, only one postemergence treatment is done. However, in horticultural crops, herbicides can be sprayed more than once to achieve a higher weed control. The case of medium patches represented about $25 \%$ of the total number of patches. The total area infested by S. halepense was almost 6 ha, which represented approximately $8 \%$ of the evaluated area. Similar results were obtained in trials with Avena sterilis L. in barley crops (Ruiz et al. 2006). This effect shows that a similar pattern between annual and perennial weeds could be reached in terms of patch size distribution.

The weed-positive data were clustered over the areas of the fields, indicated by the joint-count statistics values. Table 2 shows that randomly distributed weedy-areahad maximum half of the numbers of shared boarders than observed in the fields. Especially field "a" $(\mathrm{JC}=34$ to random $(1,000)=1.8)$ and field "d" $(\mathrm{JC}=336$ to random $(1,000)=11.2)$ represented clustered structures. Fewer numbers were determined for fields " $\mathrm{b}$ " $(\mathrm{JC}=1,209$ to random $(1,000)=610.6)$ and "f" $(\mathrm{JC}=2,766$ to random $(1,000)=1,325.2)$, but these still tended to patches. The limiting effect of the borders or its influence for the expansion of patches from the edges to the center of the field was clearly visible. The infestation was higher close to the edges, and it continuously declined as the distance to the border increased. The infestation reached its maximum level in the first $10 \mathrm{~m}$ band from the edge (Fig. 1). In addition, a higher density was also present closer to the borders. This could be a double phenomenon: the limiting effect of the border which impedes the spreading of rhizomes, or because borders become the origin of rhizome spreading into the field from the outside, where no herbicides are applied. These effects are not exclusive for the studied weed. Cirsium arvense (L.) Scop. and Agropyron repens $(\mathrm{L}$.) Gould presented a similar pattern under different tillage systems (Kelner 1995). Marshall (1989) showed that this pattern was common for weeds, which were mostly located close and out of the field edges. This behaviour suggests to focus efforts on edges, avoiding the invasion of new foci and controlling the weed spreading from these areas.

Field edges also had a great influence in patch expansion. In general, the majority of patches were longer in the direction of tillage with a few exceptions. Those patches in contact with a field border were almost five times longer than wider in the direction of tillage (Table 3). This observation was confirmed by a variogram study, analysing the data in direction of tillage, orthogonal to this and omnidirectional. It could be noticed that samples affected one another mainly 
Table 2 Counted joints of features with $S$. halepense (only one positive sample of S. halepense)

\begin{tabular}{lllllll}
\hline & Field a & Field b & Field c & Field d & Field e & Field $\mathrm{f}$ \\
\hline Counted joints & 34 & 1209 & 582 & 336 & 25 & 2,766 \\
Mean of joints $^{\mathrm{a}}$ & 1.881 & 610.581 & 177.227 & 11.172 & 4.006 & $1,325.148$ \\
& $(5.5 \%)$ & $(50.5 \%)$ & $(30.5 \%)$ & $(3.3 \%)$ & $(16.0 \%)$ & $(47.9 \%)$ \\
\hline
\end{tabular}

${ }^{a}$ Means of 1,000 random distributions (relative value random joints of counted joints)

Fig. 1 Histogram showing the percentage of $S$. halepense infestation according to the distance to field edges. Proportion of $S$. halepense infestation (levels 1,2) were measured at 5-meter intervals from the field border. Each bar corresponds to one interval. Average data for all the fields

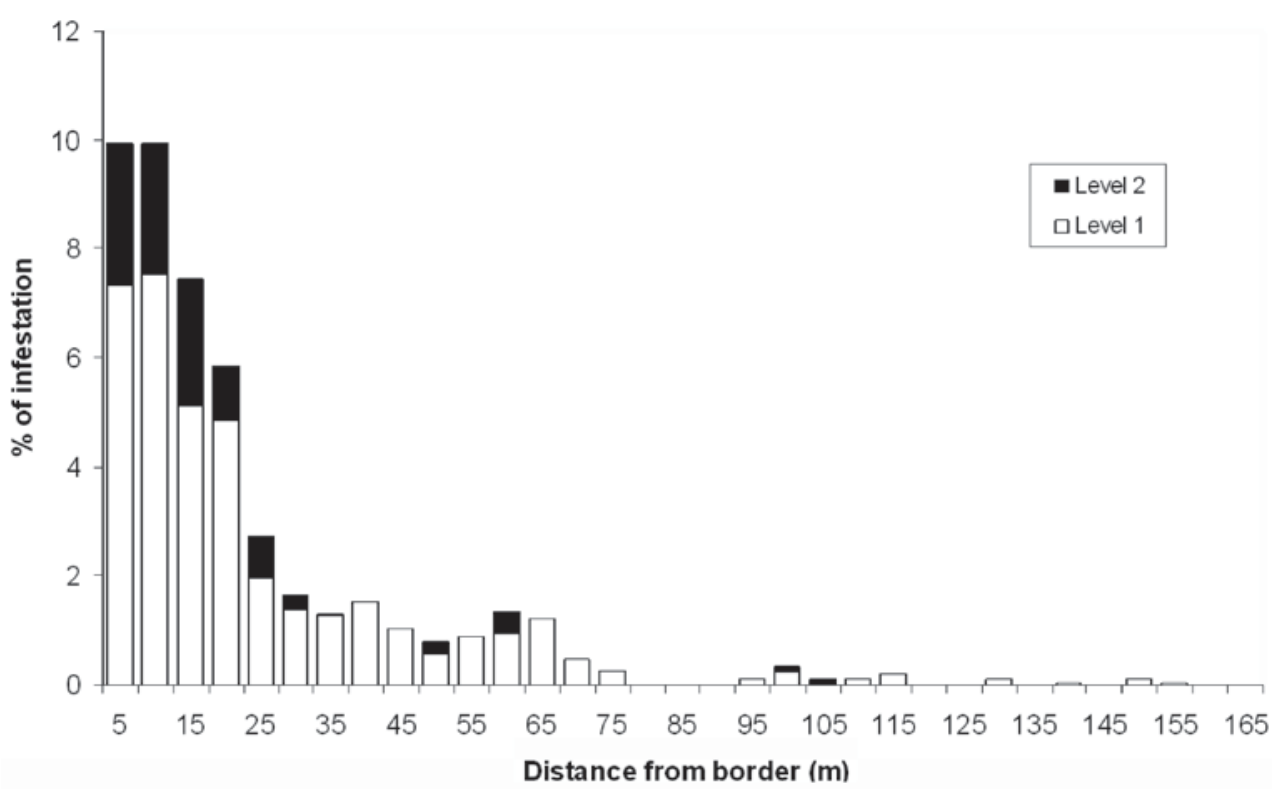

Table 3 Patch shape evolution according to the type of contact with field edges and position within the field

\begin{tabular}{lll}
\hline $\begin{array}{l}\text { Patch growth limited by a } \\
\text { field border }\end{array}$ & $\begin{array}{l}\text { Shape of patches } \\
\text { (length to wide ratio) }\end{array}$ & $\begin{array}{l}\text { Standard } \\
\text { deviation }\end{array}$ \\
\hline Perpendicular to tillage & 2.31 & 1.0 \\
Parallel to tillage & 4.99 & 2.9 \\
Both (field corner) & 1.94 & 0.8 \\
No limitation & 2.36 & 1.2 \\
\hline
\end{tabular}

in the direction of working processes. Patches located away of a border, nearby the center of the field, were more than two times longer in the direction of tillage than wider. This effect could be due to the expansion of rhizomes by tillage operations, as well as harvest, which is in accordance with the findings of Andújar et al. (2011). However, they reached higher values of anisotropy, probably caused by a lower herbicide usage in the maize field and a larger frequency of herbicide treatments in tomato fields. The effect of field borders and the anisotropic growing have been described in other studies, such as in the case of weeds in sunflower crops (Humston et al. 2005) or in seed banks (Wiles and Brodahl 2004). In a five-year study, this effect persisted along the years; Setaria viridis maps showed an anisotropic effect along the studied period (Colbach et al. 2000).
Another leading effect, similar to patch shape, is the ratio area/perimeter ${ }^{2}$, which showed a progressive diminishment in its value, i.e. patches showed a general tendency to gain shape complexity as the patch size increased (Fig. 2). This index was calculated only for patches with an area bigger than $20 \mathrm{~m}^{2}$ and not in contact with field borders, to avoid interferences by factors limiting the spatial dispersion. Therefore, patch complexity was a function of patch size with a reduction of the regularity, as they became bigger. This effect could be a result of the tillage operations with their spreading effect and also, to the joining of patches creating complex shapes. Previous studies showed that $S$. halepense did not grow in a preferential direction, but rather in circular-shaped patches (Horowitz 1973). Hence, changes in this pattern are mainly caused by human operations. A common effect was found for $S$. halepense in maize (Andújar et al. 2011) and also, in sterile oat in barley crops (Ruiz et al. 2006). The implications of shape complexity are important for site-specific weed management. The presence of regular large patches favors the precision spraying of herbicides with fewer efforts. Complex shapes lead to higher expenditures of herbicides because of the resolution of the sprayer and the higher fuel consumption required to perform more tracks, which are necessary to cover the whole infestation. 
Fig. 2 Relationship between the ratio area/perimeter ${ }^{2}$ and the patch size (logarithmic scale), for patches $>20 \mathrm{~m}^{2}$ not in contact with field borders

Fig. 3 Percentage of $S$. halepense (levels 1,2 ) in zones with different flooding risk. Error bars are indicative of the standard deviations of the analyzed fields
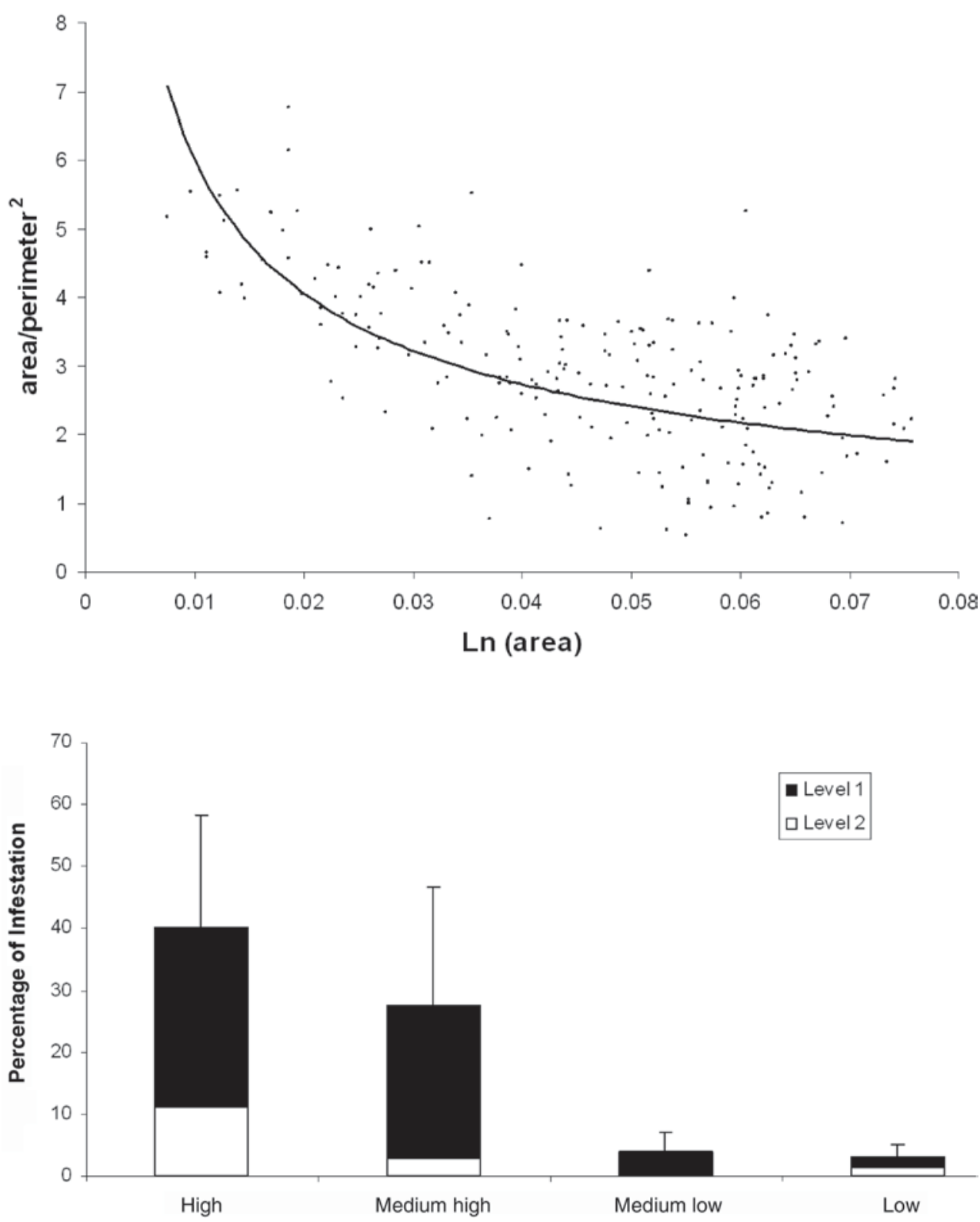

Flooding risk
The influence of flooding risk was assessed. Generally, fields had a slight slope and were located close to rivers with some risk of flooding. Since the precipitations in the evaluated regions are quite seasonal, the riverbeds tend to increase their water levels with the water invading the fields during winter. This effect was observed in most of the studied cases. Consequently, an analysis of the influence of flooding in those fields adjacent to rivers was performed. Fields were divided in four zones depending on its flooding risk (altitude respect to the riverbed). Mostly, the highest percentage of infestation was located at the lowest areas of the field. These areas were uniformly invaded by the water during the winter season. The infestation rapidly decrease in function of its distance to the riverbed (Fig. 3). This result was hypothesized to be due to the drag of seeds and rhizomes by the water over the flooded field area. Also, the possibility of higher amount of water could favor the establishment of new patches, as well as the higher moisture content of the soil in these areas.

The spatial trends observed in the evaluated field follow a common pattern with other weeds. Krohmann et al. (2006), showed similar patterns for Alopecurus myosuroides Huds. with aggregations in the fields and an anisotropic spreading of patches. This was a common pattern for different crops, as well as in this study, where $S$. halepense showed a similar tendency than a previous study dealing with maize crops 
(Andújar et al. 2011). However, the exception appeared at the lower levels of infestations in tomato fields. The lowest infestation could be attributed to the use of higher amount of herbicides and spraying frequency along the cropping period.

\section{Conclusions}

All the spatial patterns described in this study could have important implications for weed management. S. halepense infestations tended to concentrate close to the edges with a preferential spreading direction along the row. Therefore, the use of patch spraying in field borders and flooding risk areas could prevent new invasions inside of the fields. In this way, the tillage operations, the use of site-specific treatments-chemical or mechanical-could reduce the fuel consumption and improve the machinery use, saving time, money and improving the environmental impact of cropping systems.

Acknowledgements This research was funded by the Foundation Alfonso Martín Escudero.

\section{References}

Andújar D, Ruiz D, Ribeiro A, Fernández-Quintanilla C, Dorado J (2011) Spatial distribution patterns of johnsongrass (Sorghum halepense) in corn fields in spain. Weed Sci 59(1):82-89

Andújar D, Barroso J, Fernández-Quintanilla C, Dorado J (2012) Spatial and temporal dynamics of Sorghum halepense patches in maize crops. Weed Res 52(5):411-420

Barroso J, Fernandez-Quintanilla C, Ruiz D, Hernaiz P, Rew L (2004) Spatial stability of Avena sterilis ssp. ludoviciana populations under annual applications of low rates of imazamethabenz. Weed Res 44(3):178-186

Bivand R, Altman M, Anselin L, Albo RAA, Berke O, Bernat A, Blanchet G, Blankmeyer E, Carvalho M, Christensen B, Chun Y, Dormann C, Dray SA, Halbersma R, Krainski E, Legendre P, Lewin-Koh N, Li H, Ma J, Millo G, Mueller W, Ono H, PeresNeto P, Piras G, Reder M, Tiefelsdorf M, Yu. D (2013) spdep: Spatial dependence: weighting schemes, statistics and models, r package version 0.5-56

Brain P, Cousens R (1990) The effect of weed distribution on predictions of yield loss. J Appl Ecol 27:735-742

Cardina J, Sparrow D, McCoy E (1995) Analysis of spatial distribution of common lambsquarters (Chenopodium album) in no-till soybean (Glycine max). Weed Sci 43:258-268

Colbach N, Forcella F, Johnson G (2000) Spatial and temporal stability of weed populations over five years. Weed Sci 48:366-377

Dieleman J, Mortensen D (1999) Characterizing the spatial pattern of Abutilon theophrasti seedling patches. Weed Res 39:455-467
Donald WW (1994) The biology of canada thistle (Cirsium arvense). Reviews of. Weed Sci 6:77-101

European Council (2009) Directive 2009/128/ec of the european parliament and the council establishing a framework for community action to achieve the sustainable use of pesticides. Off J Eur Union 309:71-86

Gerhards R, Christensen S (2003) Real-time weed detection, decision making and patch spraying in maize, sugar beet, winter wheat and winter barley. Weed Res 43(6):385-392

Holm L (1969) Weeds problems in developing countries. Weed Sci 17(1):113-118

Horowitz M (1973) Spatial growth of Sorghum halepense (L.) pers. Weed Research 13(2):200-208

Humston R, Mortensen DA, Bjørnstad ON (2005) Anthropogenic forcing on the spatial dynamics of an agricultural weed: the case of the common sunflower. J Appl Ecol 42(5):863-872

Johnson G, Mortensen D, Gotway C (1996) Spatial and temporal analysis of weed seedling populations using geostatistics. Weed Sci 44:704-710

Kelner D (1995) The effect of zero tillage on weed population. http:// www.mandakzerotill.org/books/proceedings/proceedings $\% 20$ 1995/weed_pop.html. Accessed 5 Aug 2010

Krohmann P, Gerhards R, Kühbauch W (2006) Spatial and temporal definitions of weed patches using quantitative image analysis. J Agro Crop Sci 192:72-78

MAPA (2013) Encuesta sobre superficies y rendimientos cultivos. Secretaría General Técnica Subdirección General de Estadística. Madrid

Marshall EJP (1989) Distribution patterns of plants associated with arable field edges. J Appl Ecol 26(1):247-257

Plant R (2012) Spatial data analysis in ecology and agriculture using R. CRC Press/Taylor \& Francis Group Boca Raton 33487-2742

Ruiz D, Escribano C, Fernández-Quintanilla C (2006) Assessing the opportunity for site-specific management of Avena sterilis in winter barley fields in spain. Weed Res 46(5):379-387

Webster TM, Cardina J, Woods SJ (2000) Spatial and temporal expansion patterns of Apocynum cannabinum patches. Weed Sci 48(6):728-733

Wiles L, Brodahl M (2004) Exploratory data analysis to identify factors influencing spatial distributions of weed seed banks. Weed Sci 52:936-947

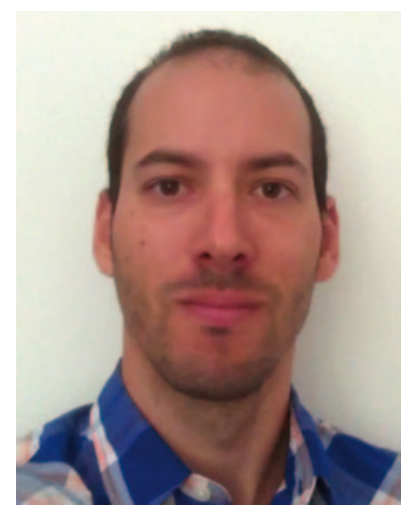

Dionisio Andújar is $\mathrm{PhD}$ in agriculture at the Polytechnic University of Madrid. He is author of several peer-review journals and patents. He was working as associate researcher at the Institute for Agricultural Sciences for the Department of Weed Sciences (CSIC, Madrid, Spain). Currently, he is Posdoctoral Researcher at the Insitute of Phytomedicine (Universtity of Hohenheim, Stuttgart, Germany) working in the development of spatio-temporal models for weed expansion and Site-specific weed management. 